OPEN ACCESS

Edited by:

Pung P. Hwang,

Academia Sinica, Taiwan

Reviewed by:

Alberto Cuesta

University of Murcia, Spain

Mathilakath Vijayan,

University of Calgary, Canada

${ }^{*}$ Correspondence:

Jaume Pérez-Sánchez jaime.perez.sanchez@csic.es

Specialty section:

This article was submitted to

Aquatic Physiology,

a section of the journal

Frontiers in Physiology

Received: 05 October 2016

Accepted: 13 January 2017

Published: 01 February 2017

Citation:

Pérez-Sánchez J, Terova G,

Simó-Mirabet P, Rimoldi S,

Folkedal O, Calduch-Giner JA, Olsen RE and Sitjà-Bobadilla A (2017)

Skin Mucus of Gilthead Sea Bream

(Sparus aurata L.). Protein Mapping and Regulation in Chronically Stressed

Fish. Front. Physiol. 8:34.

doi: 10.3389/fphys.2017.00034

\section{Skin Mucus of Gilthead Sea Bream (Sparus aurata L.). Protein Mapping and Regulation in Chronically Stressed Fish}

\author{
Jaume Pérez-Sánchez ${ }^{1 *}$, Genciana Terova ${ }^{2,3}$, Paula Simó-Mirabet ${ }^{1}$, Simona Rimoldi ${ }^{2}$, \\ Ole Folkedal ${ }^{4}$, Josep A. Calduch-Giner ${ }^{1}$, Rolf E. Olsen ${ }^{4,5}$ and Ariadna Sitjà-Bobadilla ${ }^{6}$ \\ ${ }^{1}$ Nutrigenomics and Fish Growth Endocrinology Group, Biology, Culture and Pathology of Marine Species, Institute of \\ Aquaculture Torre de la Sal (IATS-CSIC), Castellón, Spain, ${ }^{2}$ Department of Biotechnology and Life Sciences, University of \\ Insubria, Varese, Italy, ${ }^{3}$ Inter-University Centre for Research in Protein Biotechnologies "The Protein Factory" Polytechnic \\ University of Milan and University of Insubria, Varese, Italy, ${ }^{4}$ Institute of Marine Research Matre, Matredal, Norway, \\ ${ }^{5}$ Department of Biology, Norwegian University for Science and Technology, Trondheim, Norway, ${ }^{6}$ Fish Pathology Group \\ Group, Biology, Culture and Pathology of Marine Species, Institute of Aquaculture Torre de la Sal (IATS-CSIC), Castellón, \\ Spain
}

The skin mucus of gilthead sea bream was mapped by one-dimensional gel electrophoresis followed by liquid chromatography coupled to high resolution mass spectrometry using a quadrupole time-of-flight mass analyzer. More than 2,000 proteins were identified with a protein score filter of 30. The identified proteins were represented in 418 canonical pathways of the Ingenuity Pathway software. After filtering by canonical pathway overlapping, the retained proteins were clustered in three groups. The mitochondrial cluster contained 59 proteins related to oxidative phosphorylation and mitochondrial dysfunction. The second cluster contained 79 proteins related to antigen presentation and protein ubiquitination pathways. The third cluster contained 257 proteins where proteins related to protein synthesis, cellular assembly, and epithelial integrity were over-represented. The latter group also included acute phase response signaling. In parallel, two-dimensional gel electrophoresis methodology identified six proteins spots of different protein abundance when comparing unstressed fish with chronically stressed fish in an experimental model that mimicked daily farming activities. The major changes were associated with a higher abundance of cytokeratin 8 in the skin mucus proteome of stressed fish, which was confirmed by immunoblotting. Thus, the increased abundance of markers of skin epithelial turnover results in a promising indicator of chronic stress in fish.

Keywords: chronic stress, cytokeratins, gilthead sea bream, proteome, skin mucus

\section{INTRODUCTION}

A keratinized multi-sheet cellular layer (stratum corneum) covers the epidermis of amphibian adults, reptiles, birds and mammals, whereas skin mucus constitutes the outermost epidermal barrier in fish and aquatic amphibian larvae (Schempp et al., 2009). Cutaneous or skin mucus is thus considered a metabolically active tissue with important roles in respiration, ionic and osmotic regulation, excretion, locomotion, communication, sensory perception, thermal regulation and 
immunological defense (Negus, 1963; Shephard, 1994; Cone, 2009; Esteban, 2012). Several cell types are involved in regulating the composition of the skin mucus layer, although it is mainly shaped by Goblet cells that release mucous granules containing high molecular weight glycoproteins called mucins (Dharmani et al., 2009). These O-glycosylated glycoproteins are present on the apex of all wet-surfaced epithelia with a well-defined expression pattern, which can be disrupted in response to a wide range of injuries or challenges. For instance, recent experiments in gilthead sea bream (Sparus aurata L.) indicate that the gene expression pattern of gut mucins is altered by dietary oils and parasitic enteritis (Pérez-Sánchez et al., 2013b). In addition to glycoproteins, glycosaminoglycans, immunoglobulins, lectins, pheromones, and proteolytic enzymes have been identified in the mucus of different fish species (Fletcher and Grant, 1969; Hjelmeland et al., 1983; van de Winkel et al., 1986; Shiomi et al., 1988; Shephard, 1994; Subramanian et al., 2008; Guardiola et al., 2014; Ren et al., 2015). Most of these molecules are involved in fish innate immunity and skin mucus is considered a key component of fish immune responses (Ellis, 2001; Salinas et al., 2011; Esteban, 2012). This is certainly the result of the evolutionary adaptation of fish to survive in a variety of aquatic environments which are rich in pathogenic organisms. However, immune response can be depleted by stressful conditions, such as those resulting from high density or inappropriate aquaculture husbandry. Thus, limiting stress is now considered a key issue to reduce the economic losses due to opportunistic pathogens in intensive fish farming (Mancuso, 2012).

In teleost fish, stress activates the hypothalamus-pituitaryinterrenal axis, leading to a rapid release of the glucocorticoid hormone cortisol by the interrenal tissue, the tissue analogous to the adrenal cortex of mammals (Pottinger, 2008; Pankhurst, 2011). Thus, high circulating levels of cortisol are commonly used as indicators of fish acute stress, though there is no consensus on the endocrine profile for chronically stressed animals or how to assess it without invoking further stress (Pankhurst, 2011; Dickens and Romero, 2013). This notion applies to gilthead sea bream exposed to chronic and acute stress (Arends et al., 1999; Rotllant et al., 2000; Calduch-Giner et al., 2010; Fanouraki et al., 2011), even in a higher manner when intermittent and repetitive stressors are considered (Tort et al., 2001; Ibarz et al., 2007). Hence, expression profiling of stress-responsive genes in different target tissues is envisaged as a complementary tool for assessing nutritional and environmental stress in fish (Terova et al., 2005, 2009; Rimoldi et al., 2012, 2016; Montero et al., 2015a,b), and gilthead sea bream in particular (Pérez-Sánchez et al., 2013a; Benedito-Palos et al., 2014; Bermejo-Nogales et al., 2014). However, this type of approach often requires sacrificing specimens, and the use of a biological sample collected in a minimally invasive manner is more advisable. Skin mucus fulfills such specifications, especially taking into account that one of the most apparent responses of fish to stress is the production of a copious amount of skin mucus (Vatsos et al., 2010). Thus, stress associated with live transport increased the production of sulfated and sialyated skin mucins in channel catfish (Tacchi et al., 2015). Ai-Jun et al. (2013) identified lectins and cytokeratins of skin mucus as bioindicators of thermal stress in turbot.
Sea lice infestation increased the abundance of lectins in the skin mucus of Atlantic salmon (Easy and Ross, 2009), while transcriptional and proteomic approaches revealed differentially expressed proteins in the skin mucus of Atlantic cod upon natural infection with Vibrio anguillarum (Rajan et al., 2013). Likewise, metabolite profiling of fish skin mucus has been successfully applied as a novel approach for the monitoring and surveillance of wild fish health (Ekman et al., 2015; Dzul-Caamal et al., 2016).

Recently, important research efforts have also been invested in mapping the skin mucus proteome of warm-water marine fish, such as gilthead sea bream (Jurado et al., 2015; Sanahuja and Ibarz, 2015; Cordero et al., 2016) and European sea bass (Cordero et al., 2015), which are the two most important species in Mediterranean aquaculture. These studies have made important advances in defining the composition of fish mucus, also highlighting that both probiotics and overcrowding stress induce proteomic changes mostly involved in immune processes. However, so far, very little is known about the effects of other types of stressors that are closely related to daily farming activities, such as people walking alongside tanks, removal of dead fish, and changes in noise and/or light level that potentially provoke a wide variety of stimuli that are difficult to evaluate in a non-invasive and easy manner (Bratland et al., 2010; Nilsson et al., 2012). Thus, the goal of the present study was to gain new insights into the mucus composition of gilthead sea bream, contributing to identify robust and non-invasive biomarkers in a chronic stress model of daily farming activities, which have been previously characterized by means of more conventional stress biomarkers of fish performance at hormonal and liver transcriptional levels (Bermejo-Nogales et al., 2014). To pursue this issue, one-dimensional and two-dimensional proteomic approaches followed by mass spectrometry were combined, taking advantage of a homologous protein database derived from the IATS-CSIC gilthead sea bream transcriptome (Calduch-Giner et al., 2013) for consistent and reliable protein matches.

\section{MATERIALS AND METHODS}

\section{Animals and Mucus Collection}

Two-year old gilthead sea bream (average body weight of $320 \mathrm{~g}$ ) coming from the study of Bermejo-Nogales et al. (2014) comprised a control unstressed group (CTRL) and a group of fish exposed to a model of chronic stress that consisted in a fast series of automated stressors (multiple sensorial stressed fish, M-ST): tank shaking, sounds, moving objects into water, water reverse flow and light flashes in random order for $30 \mathrm{~min}$ three times a day $(9: 30 \mathrm{~h}, 14: 30 \mathrm{~h}$, and $18: 30 \mathrm{~h}$ ) for a period of 21 days. At the end of experimental period, eight fish per group were randomly sampled and anesthetized with $100 \mathrm{mg} / \mathrm{L}$ MS-222 (Sigma, Saint Louis, MO, USA). Mucus was gently scraped off the normal skin surface of the left side of fish from operculum to tail with sterile microslides, avoiding collection of blood, urine, and feces along with mucus. Skin mucus was then transferred into Eppendorf tubes and immediately frozen at $-80^{\circ} \mathrm{C}$ until analyzed. All procedures were performed wearing gloves to avoid human 
contaminations and according to the Norwegian National Ethics Board for experimentation with animals (ID No. 4007) and EU legislation $(2010 / 63 / \mathrm{EU})$ on the handling of experimental animals.

\section{One-Dimensional Electrophoresis}

The protein composition of mucus was first analyzed by onedimensional electrophoresis (1-DE). Initially, mucus samples from all animals (CTRL and M-ST fish) were pooled, and triplicate samples (54-56 $\mu \mathrm{g}$ ) were separated by sodium dodecyl sulfate polyacrylamide gel electrophoresis (SDS-PAGE) using a TGX Any kD precast gel (Bio-Rad, Hercules, CA, USA) run at 200V for $25 \mathrm{~min}$ and stained overnight with colloidal Coomassie (Bio-Rad). The gel was then divided into 10 slices $(0.65 \mathrm{~cm})$ that were analyzed independently. Proteins in the gel were digested with protein-grade trypsin (Promega, Madison, WI, USA) and concentrated by speed vacuum at a final volume of $12 \mu \mathrm{L}$ for mass spectrometry.

\section{Two-Dimensional Electrophoresis}

Individual samples of CTRL and M-ST fish $(n=8$ for each group) were precipitated by means of the 2-D Clean-Up kit (GE HealthCare Life Sciences, Buckinghamshire, UK), and then solubilized in labeling buffer (7 M urea, $2 \mathrm{M}$ thiourea, $4 \% \mathrm{w} / \mathrm{v}$ CHAPS, $20 \mathrm{mM}$ Tris). The N-hydroxysuccinimide ester dyes Cy2/3/5 were used for minimal labeling following the mixed internal standard methodology of Alban et al. (2003) according to the manufacturer's protocol (GE HealthCare Life Sciences). Briefly, $50 \mu \mathrm{g}$ of each experimental sample were individually labeled with 400 pmol of either Cy3 or Cy5. In parallel, a mixed internal standard was generated by combining equal amounts of each experimental sample, which were then labeled with 400 pmol of Cy2. Labeling was performed for $60 \mathrm{~min}$ on ice in the dark after which the reaction was quenched by adding $10 \mathrm{nM}$ lysine for $10 \mathrm{~min}$.

About $150 \mu \mathrm{g}$ of protein (incubated in $65 \mathrm{mM}$ DTT and $1 \%$ ampholytes) were loaded into Immobiline DryStrips $(\mathrm{pH}$ 3-11 NL, $24 \mathrm{~cm}$ ), rehydrated overnight in $8 \mathrm{M}$ urea, $4 \% \mathrm{w} / \mathrm{v}$ CHAPS, $12 \mu \mathrm{L} / \mathrm{mL}$ DeStreak reagent, $1 \%$ ampholytes. After focusing at $32 \mathrm{kVh}$ at $20^{\circ} \mathrm{C}$, strips were equilibrated first for $15 \mathrm{~min}$ in reducing solution (6 M urea, $50 \mathrm{mM}$ Tris- $\mathrm{HCl}, 30 \%$ $\mathrm{v} / \mathrm{v}$ glycerol, $2 \% \mathrm{w} / \mathrm{v}$ SDS, $2 \% \mathrm{w} / \mathrm{v}$ DTT) and then in alkylating solution (6 M urea, $50 \mathrm{mM}$ Tris- $\mathrm{HCl}, 30 \% \mathrm{v} / \mathrm{v}$ glycerol, $2 \% \mathrm{w} / \mathrm{v}$ SDS, $2.5 \% \mathrm{w} / \mathrm{v}$ iodoacetamide) for $15 \mathrm{~min}$. The second dimension $(12.5 \%$ polyacrylamide, $25 \times 21 \mathrm{~cm})$ was run at $20^{\circ} \mathrm{C}$ at a constant power of $2 \mathrm{~W}$ for $60 \mathrm{~min}$ followed by $15 \mathrm{~W}$ until the bromophenol blue tracking front had run off the end of the gel $(6 \mathrm{~h})$. Fluorescence images were obtained on a Typhoon 9,400 scanner (GE HealthCare Life Sciences). Cy2, Cy3, and Cy5 images were scanned at excitation/emission wavelengths of $488 / 520 \mathrm{~nm}, 532 / 580 \mathrm{~nm}$, and $633 / 670 \mathrm{~nm}$, respectively, at a resolution of $100 \mu \mathrm{m}$. Image analysis was performed using DeCyder v.6.5 software (GE HealthCare Life Sciences). Protein spots displaying a statistically significant difference between groups were manually excised from analytical gels and digested with sequencing-grade trypsin prior to mass spectrometry analysis.

\section{Mass Spectrometry}

Samples $(5 \mu \mathrm{l})$ from 1-DE and two-dimensional electrophoresis (2-DE) were analyzed by liquid chromatography coupled to highresolution mass spectrometry (LC-HRMS) using a quadrupole time-of-flight mass analyzer (qQTOF). Briefly, samples were loaded onto a trap column (NanoLC Column, $3 \mu$ C18-CL, $350 \mu \mathrm{m} \times 0.5 \mathrm{~mm}$, Nikkyo Technos Co. Ltd., Tokyo, Japan) desalted with $0.1 \%$ TFA at $3 \mu \mathrm{L} / \mathrm{min}$ for $10 \mathrm{~min}$. Peptide mixtures were then loaded onto an analytical column (LC Column, $3 \mu$ C18-CL, $75 \mu \mathrm{m} \times 12 \mathrm{~cm}$, Nikkyo Technos Co. Ltd.) equilibrated in $5 \%$ acetonitrile and $0.1 \%$ formic acid. Separation was carried out with a linear gradient of 5-40\% acetonitrile gradient with $0.1 \%$ formic acid at a flow rate of $300 \mathrm{~nL} / \mathrm{min}$. Peptides were analyzed in a high resolution nanoESI (qQ) TOF mass spectrometer (AB SCIEX TripleTOF 5,600 System, Applied Biosystems/MDS Sciex, Foster City, CA). The (qQ) TOF was operated in information-dependent acquisition mode, in which a 0.25 -s TOF MS scan from 350 to $1,250 \mathrm{~m} / \mathrm{z}$, was performed, followed by $0.05 \mathrm{~s}$ product-ion scans from 100 to $1,500 \mathrm{~m} / \mathrm{z}$ on the 50 most intensely $2-5$ charged ions. The MS proteomics data have been deposited to the ProteomeXchange Consortium via the PRIDE partner repository with the dataset identifiers PXD004115 and PXD004116.

Protein identity was determined using ProteinPilot v4.5 (AB SCIEX, Applied Biosystems/MDS Sciex), which incorporated the Mascot search algorithm (v2.2, Matrix Science, London, UK). ProteinPilot default parameters were used to generate peak list directly from 5,600 TripleTOF wiff files. Mascot was used to search the Expasy protein database or the IATS-CSIC gilthead sea bream database (www.nutrigroup-iats.org/seabreamdb) according to the following parameters: trypsin specificity, carbamidomethyl $\mathrm{C}$ to fix modification, deamidated (NQ), Gln->pyro-Glu (N-term Q), Glu->pyro-Glu (N-term E), oxidation (M) to variable modification, $75 \mathrm{ppm}$ as peptide mass tolerance and 0.6 Da as fragment mass tolerance. Proteins with a ProteinPilot score higher than 1.3 were identified with a confidence interval $\geq 95 \%$. Functional analysis of identified proteins was performed by means of the Ingenuity Pathway Analysis (IPA) software (www.ingenuity.com). For each protein in the analysis, the Uniprot accession equivalent for one of the three higher vertebrates model species in IPA (human, rat, or mouse) was searched as previously reported for the transcriptome-encoding proteins of gilthead sea bream (Calduch-Giner et al., 2013).

\section{Western Blot}

In order to validate the results of 2-DE analysis, the increased abundance of keratin type II cytoskeletal 8 in M-ST compared to CTRL group was assessed by means of a Western blot analysis using an antibody directed to human cytokeratin 8 . Total protein concentration from mucus samples of CTRL and M-ST fish was determined using the Bradford protein assay (Bio-Rad). The quantified protein analyzed remained almost equal in both experimental groups $(1 \mu \mathrm{g} / \mu \mathrm{l})$ and equal amounts from the two different groups were mixed with $2 \times$ SDS sample buffer (1.5 M Tris, $\mathrm{pH} 8.8,0.2 \%$ glycerol, $0.4 \%$ SDS, $0.1 \% 2$ mercaptoethanol and $0.05 \%$ bromophenol blue), heated for 5 
min at $50^{\circ} \mathrm{C}$ and separated by SDS-PAGE. After electrophoresis, proteins were transferred to polyvinylidenedifluoride (PVDF) membranes (Invitrogen, Gaithersburg, MD, USA) at $15 \mathrm{~V}$ for $1 \mathrm{~h}$ at room temperature. The membranes were then blocked in 5\% nonfat dry milk prepared in TBS $(20 \mathrm{Mm}$ Tris $\mathrm{pH} 7.5,500 \mathrm{mM} \mathrm{NaCl}$ ) overnight at $4^{\circ} \mathrm{C}$. After blocking, membranes were incubated with rabbit anti-human cytokeratin 8 antibody (PA5-29607, Thermo Scientific, Wilgminton, DE, USA) in antibody buffer $(0.1 \%$ Tween $20,1 \%$ bovine serum albumin), using a 1:2000 dilution of the supplied antibody concentration. The peptide immunogen (252 amino acids in length) of this primary antibody shared $81 \%$ identity (93\% homology) with the gilthead sea bream sequence of cytokeratin 8. After primary antibody incubation, membranes were washed four times for $10 \mathrm{~min}$ each in T-TBS (TBS with $0.1 \%$ Tween 20), incubated with HRP-conjugated goat anti-rabbit IgG at 1:9000 dilution in antibody buffer for 2 $\mathrm{h}$ at room temperature, and washed four times for $10 \mathrm{~min}$ each in T-TBS. Immunodetection was performed using a chemiluminescent system (Western Blotting Luminol Reagent, Santa Cruz Biotechnologies, CA, USA) and the image on the membrane was captured by VersaDoc Imaging system model 5,000 .

\section{Statistical Analyses}

Quantification of relative protein levels in 2-DE electrophoresis was performed using Decyder v.6.5 software. Statistical significance was assessed using Student's $t$-test $(p<0.05)$ applying the false discovery rate (FDR) to minimize the number of false positive results. Western blot band intensity was quantified using Quantity One 1-D Analysis Software 4.5 (Bio-Rad) and results were compared by means of Student's $t$-test. The significance threshold was set at $p<0.05$.

\section{RESULTS AND DISCUSSION}

\section{Skin Mucus Proteins in Gilthead Sea Bream}

The current study analyzed the skin mucus of gilthead sea bream, combining 1-DE and 2-DE MS-based proteomic approaches. The primary finding was the large number of proteins that were identified by $1-\mathrm{DE}$ followed by LC-HRMS in comparison to previous proteomic studies in this fish species, in which attention was focused on the most abundant proteins with an over-representation of structural and immune-related proteins. Hence, in the first reference proteome map of gilthead sea bream epidermal mucus (Sanahuja and Ibarz, 2015), up to 92 proteins were identified, and the Gene Ontology enrichment process

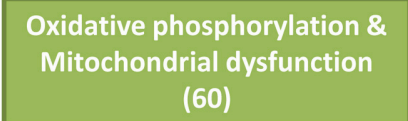

(60)

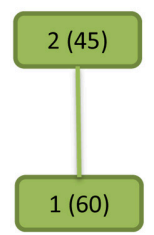

\section{Canonical pathway}

1 Mitochondrial dysfunction

2 Oxidative phosphorylation

3 Antigen presentation pathway

4 Protein ubiquitination pathway

5 Actin cytoskeleton signaling

6 Acute phase response signaling

7 Clathrin-mediated endocytosis signaling

EIF2 signaling

Epithelial adherens junction signaling

10 Integrin signaling

11 mTOR signaling

12 Regulation of actin based motility by Rho

13 Regulation of elF4 end p70S6K signaling

14 RhoA signaling

15 RhoGDI signaling

16 Remodelling of epithelial adherens junctions

17 Signaling by Rho family GTPase
Protein ubiquitination \& Antigen presentation (79)

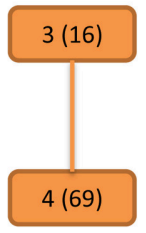

Protein synthesis, Cellular assembly and remodeling \& Non-humoral immune response (257)

FIGURE 1 | Overlapping canonical pathway network from gilthead sea bream skin mucus proteins. This was generated by using Ingenuity Pathway Analysis (IPA) tools. Settings were selected to guarantee a minimum of six common proteins between different canonical pathways. Solid lines show a direct connection between canonical pathways. Numbers assigned to each canonical pathway are represented in the table appended, and numbers in parentheses indicate the number of proteins in each pathway or cluster. 
TABLE 1 | Proteins mapped in the overlapping pathways of oxidative phosphorylation and mitochondrial dysfunction.

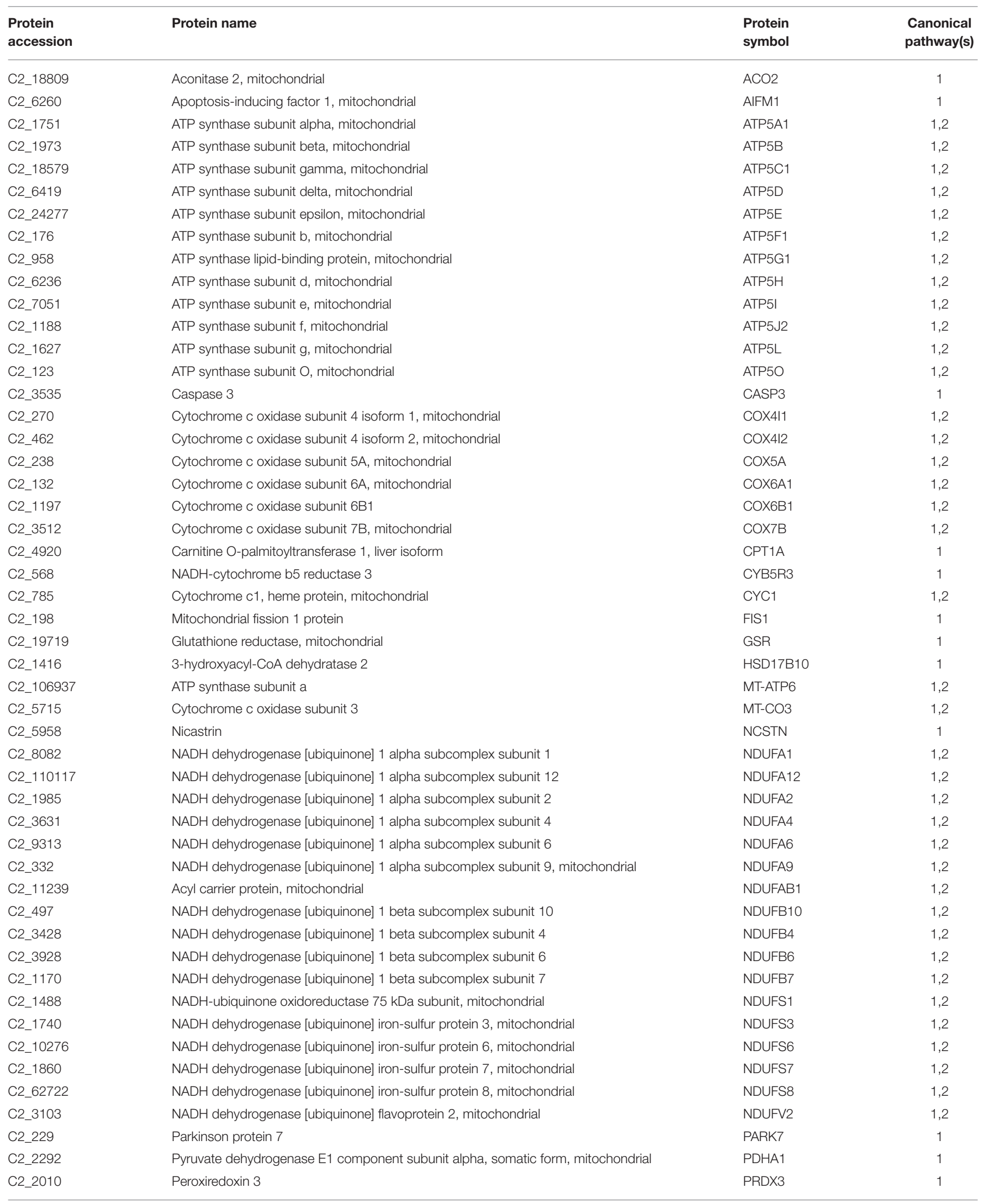




\begin{tabular}{|c|c|c|c|}
\hline $\begin{array}{l}\text { Protein } \\
\text { accession }\end{array}$ & Protein name & Protein symbol & Canonical pathway(s) \\
\hline C2_4821 & Peroxiredoxin 5 & PRDX5 & 1 \\
\hline C2_1571 & Succinate dehydrogenase [ubiquinone] flavoprotein subunit, mitochondrial & SDHA & 1,2 \\
\hline C2_791 & Succinate dehydrogenase [ubiquinone] iron-sulfur subunit, mitochondrial & $\mathrm{SDHB}$ & 1,2 \\
\hline C2_1642 & Superoxide dismutase 2, mitochondrial & SOD2 & 1 \\
\hline C2_1166 & Ubiquinol-cytochrome c reductase, complex III subunit X & UQCR10 & 1,2 \\
\hline C2_516 & Ubiquinol-cytochrome c reductase binding protein & UQCRB & 1,2 \\
\hline C2_507 & Ubiquinol-cytochrome c reductase, Rieske iron-sulfur polypeptide 1 & UQCRFS1 & 1,2 \\
\hline C2_2118 & Ubiquinol-cytochrome c reductase hinge protein & UQCRH & 1,2 \\
\hline C2_12420 & Ubiquinol-cytochrome c reductase, complex III subunit VII, 9.5kDa & UQCRQ & 1,2 \\
\hline C2_318 & Voltage-dependent anion-selective channel protein 1 & VDAC1 & 1 \\
\hline
\end{tabular}

Canonical pathways are indicated by number: (1) Mitochondrial dysfunction; (2) Oxidative phosphorylation.

resulted in 12 functional groups of proteins further classified as structural, metabolic and protection-related proteins. Likewise, a limited set of proteins clustered on structural (23), metabolic (25), stress-response proteins (2) and signal transduction (2) were already reported by Jurado et al. (2015). In Atlantic salmon, up to 521 proteins were identified and classified into nine main groups based on their putative biological processes (Provan et al., 2013). In the present study, 1,595 HRMS spectra were identified by comparing the results of the ProteinPilot with the Expasy protein database when the protein score filter was set up at 1.3. However, by using our gilthead sea bream protein database we identified 2,466 spectra with a much higher protein score $(\geq 20)$. This number was significantly reduced to 2,060 when a protein score filter of 30 was applied (Table S1), but even in this case, the number of identified proteins was relatively high compared to the proteins that compose other mucosal tissues and body fluids in humans (de Souza et al., 2006; Lee et al., 2009; Marimuthu et al., 2011) and other animal models (Sánchez-Juanes et al., 2013; Bennike et al., 2014; Winiarczyk et al., 2015). Certainly, this was favored by the use of a homologous protein database derived from a reference transcriptome with a high coverage of protein-codifying sequences (more than 15,000 unique sequences in Swissprot database), which first increased the consistency of annotation in parallel with the number of protein isoforms or subunits of a given enzyme or protein complex represented in the analyzed samples (e.g., enzyme subunits of the mitochondrial respiratory chain; protein subunits of the eukaryotic translation initiation factor; ribosomal proteins; proteasome subunits, etc.). Alternatively, we cannot exclude differences in fish species regarding turnover of epidermal cells, which might trigger an enhanced flux of proteins from the cutaneous epithelium toward the skin mucus layer as a result of a normal mucus secretion and/or tissue repair and cell desquamation and renewal. This is perhaps more common than initially expected, as the results of our experimental stress model points out.

\section{Protein Characterization and Function}

Among the final number of mucus proteins $(2,060)$, more than $89 \%$ ( 1,848 proteins) were eligible for functional pathway analysis using the IPA software. These proteins were represented in 418 canonical pathways out of 644 . To easy identify the more relevant pathways and biological processes, an overlapping analysis was performed with a filter of six common proteins among related pathways. From this integrative approach, 17 canonical pathways with significant $p$-values lower than $1 \mathrm{E}-08$ were clustered in three distinct clusters (Figure 1). The first cluster was composed of 60 proteins comprising the canonical pathways "oxidative phosphorylation" and "mitochondrial dysfunction" with a high representation of enzyme subunits of the mitochondrial respiratory chain (NADH dehydrogenase, Complex I; succinate dehydrogenase, Complex II; ubiquinol-cytochrome c reductase, Complex III; cytochrome c oxidase, Complex IV; ATP synthase, Complex V) and mitochondrial cell death and disease factors with both apoptotic (apoptosis-inducing factor 1, caspase 3) and anti-apoptotic (peroxiredoxin 3, PRDX3; peroxiredoxin 5, PRDX5; superoxide dismutase 2, SOD2; Parkinson protein 7, PARK7; nicastrin, NCSTN) roles due to their mediated effects on cell proteolysis, redox sensing, and cell differentiation and proliferation (Table $\mathbf{1}$ ).

As pointed out by Sanahuja and Ibarz (2015), it is still not clear whether the mucus release of glycolytic or mitochondrial enzymes is related to Goblet cell activity or directly to high metabolic activity in the cells of epithelial layers. In any case, increased glycolytic activity has been reported during epidermal infection in Atlantic salmon (Provan et al., 2013) or parental care and mouth-brooding of cichlids (Chong et al., 2006; Iq and Shu-Chien, 2011). Meanwhile, caspase 1 and 6 have been identified in the skin mucus of European sea bass, and it has been suggested that secretion of these cysteine proteases is activated upon danger signals to amplify the inflammatory response (Cordero et al., 2015). The presence of these two caspases was also found in the present study, in addition to a third caspase that was identified as caspase 3. Importantly the caspase 3 cascade is activated by pro-apoptotic mitochondrial molecules such as cytochrome c, and restrained by cellular inhibitors of apoptosis proteins (Srinivasula and Ashwell, 2008). Indeed, elevated levels of caspase 3 in the bloodstream of human patients are considered a symptom of recent myocardial infarction (Agosto et al., 2011). Likewise, PRDXs represent a family of antioxidant proteins with a ubiquitous and differentially 
TABLE 2 | Proteins mapped in the overlapping pathways of protein ubiquitination and antigen presentation.

\begin{tabular}{|c|c|c|c|}
\hline Protein accession & Protein name & Protein symbol & Canonical pathway(s) \\
\hline C2_17008 & Anaphase-promoting complex subunit 11 & ANAPC11 & 4 \\
\hline C2_6 & Beta-2-microglobulin & B2M & 3,4 \\
\hline C2_1023 & Calreticulin & CALR & 3 \\
\hline C2_5322 & DnaJ homolog subfamily $\mathrm{C}$ member 17 & DNAJC17 & 4 \\
\hline C2_8665 & DnaJ homolog subfamily $\mathrm{C}$ member 22 & DNAJC22 & 4 \\
\hline C2_121377 & HLA class II histocompatibility antigen, DP beta 1 chain & HLA-DPB1 & 3 \\
\hline C2_104432 & $\mathrm{H}-2$ class II histocompatibility antigen, A-R alpha chain & HLA-DQA1 & 3 \\
\hline C2_728 & DLA class II histocompatibility antigen, DR-1 beta chain & HLA-DR1 & 3 \\
\hline C2_1490 & Endoplasmin (GRP-94) & HSP90B1 & 4 \\
\hline C2_6720 & Heat shock $70 \mathrm{kDa}$ protein 4 & HSPA4 & 4 \\
\hline C2_25027 & $78 \mathrm{kDa}$ glucose-regulated protein & HSPA5 & 4 \\
\hline C2_4763 & Heat shock cognate $71 \mathrm{kDa}$ protein & HSPA8 & 4 \\
\hline C2_82883 & Stress-70 protein, mitochondrial & HSPA9 & 4 \\
\hline C2_10046 & Heat shock protein beta- 11 & HSPB11 & 4 \\
\hline C2_5222 & $60 \mathrm{kDa}$ heat shock protein, mitochondrial & HSPD1 & 4 \\
\hline C2_4023 & $10 \mathrm{kDa}$ heat shock protein, mitochondrial & HSPE1 & 4 \\
\hline C2_2116 & Heat shock protein $105 \mathrm{kDa}$ & $\mathrm{HSPH} 1$ & 4 \\
\hline C2_121640 & Major histocompatibility complex class I-related gene protein & MR1 & 3 \\
\hline C2_303 & Proteasome subunit beta type-1-B & PSMB1 & 4 \\
\hline C2_53426 & Proteasome subunit beta type- 10 & PSMB10 & 4 \\
\hline C2_4220 & Proteasome subunit beta type- 2 & PSMB2 & 4 \\
\hline C2_1113 & Proteasome subunit beta type- 3 & PSMB3 & 4 \\
\hline C2_1989 & Proteasome subunit beta type-4 (Fragment) & PSMB4 & 4 \\
\hline C2_2719 & Proteasome subunit beta type- 5 & PSMB5 & 3,4 \\
\hline C2_104936 & Proteasome subunit beta type-6-B like protein & PSMB6 & 3,4 \\
\hline C2_4274 & Proteasome subunit beta type-9 & PSMB9 & 3,4 \\
\hline C2_4264 & $26 S$ protease regulatory subunit 4 & PSMC1 & 4 \\
\hline C2_3002 & $26 S$ protease regulatory subunit 7 & PSMC2 & 4 \\
\hline C2_1666 & $26 S$ protease regulatory subunit $6 \mathrm{~A}$ & PSMC3 & 4 \\
\hline C2_482 & $26 \mathrm{~S}$ protease regulatory subunit $6 \mathrm{~B}$ & PSMC4 & 4 \\
\hline C2_514 & $26 S$ protease regulatory subunit 8 & PSMC5 & 4 \\
\hline C2_1520 & $26 \mathrm{~S}$ protease regulatory subunit $10 \mathrm{~B}$ & PSMC6 & 4 \\
\hline C2_2728 & $26 S$ proteasome non-ATPase regulatory subunit 1 & PSMD1 & 4 \\
\hline C2_3102 & 26S proteasome non-ATPase regulatory subunit 11 & PSMD11 & 4 \\
\hline C2_1392 & $26 \mathrm{~S}$ proteasome non-ATPase regulatory subunit 12 & PSMD12 & 4 \\
\hline C2_790 & $26 S$ proteasome non-ATPase regulatory subunit 13 & PSMD13 & 4 \\
\hline
\end{tabular}


TABLE 2 | Continued

\begin{tabular}{|c|c|c|c|}
\hline Protein accession & Protein name & Protein symbol & Canonical pathway(s) \\
\hline C2_807 & $26 S$ proteasome non-ATPase regulatory subunit 14 & PSMD14 & 4 \\
\hline C2_4556 & $26 S$ proteasome non-ATPase regulatory subunit 2 & PSMD2 & 4 \\
\hline C2_1006 & $26 S$ proteasome non-ATPase regulatory subunit 3 & PSMD3 & 4 \\
\hline C2_8032 & $26 S$ proteasome non-ATPase regulatory subunit 6 & PSMD6 & 4 \\
\hline C2_364 & $26 S$ proteasome non-ATPase regulatory subunit 7 & PSMD7 & 4 \\
\hline C2_52053 & Proteasome activator complex subunit 2 & PSME2 & 4 \\
\hline C2_159 & S-phase kinase-associated protein 1 & SKP1 & 4 \\
\hline C2_6616 & Antigen peptide transporter 1 & TAP1 & 3,4 \\
\hline C2_8891 & Antigen peptide transporter 2 & TAP2 & 3,4 \\
\hline C2_27605 & Tapasin & TAPBP & 3 \\
\hline C2_8231 & Ubiquitin-like modifier-activating enzyme 1 & UBA1 & 4 \\
\hline C2_5227 & Ubiquitin-conjugating enzyme E2 D2 & UBE2D2 & 4 \\
\hline C2_187 & Ubiquitin-conjugating enzyme E2 D3 & UBE2D3 & 4 \\
\hline C2_17030 & Ubiquitin-conjugating enzyme E2 N & UBE2N & 4 \\
\hline C2_23677 & Ubiquitin-conjugating enzyme E2 variant $1 \mathrm{C}$ & UBE2V1 & 4 \\
\hline C2_9398 & Ubiquitin-protein ligase E3A & UBE3A & 4 \\
\hline C2_5640 & Ubiquitin carboxyl-terminal hydrolase isozyme L1 & UCHL1 & 4 \\
\hline C2_660 & Ubiquitin carboxyl-terminal hydrolase isozyme L3 & UCHL3 & 4 \\
\hline C2_1964 & Ubiquitin carboxyl-terminal hydrolase 14 & USP14 & 4 \\
\hline C2_11890 & Ubiquitin carboxyl-terminal hydrolase 22 & USP22 & 4 \\
\hline C2_18121 & Ubiquitin carboxyl-terminal hydrolase 37 & USP37 & 4 \\
\hline
\end{tabular}

Canonical pathways are indicated by number: (3) Antigen presentation pathway; (4) Protein ubiquitination pathway.

regulated abundance in tissues, mucosal surfaces and body fluids (Leyens et al., 2003; Perkins et al., 2015). In the present study, up to four PRDXs (PRDX 1, 4, 5, and 6) were detected in the skin mucus of gilthead sea bream, although only the PRDX5 was represented in the mitochondrial cluster after filtering by canonical pathway overlapping. As reported below, no changes in the abundance of PRDX5 were found in our chronic stress model, although it is noteworthy that this mitochondrial PRDX is highly regulated at the transcriptional level by a wide range of nutritional and environmental stressors (dietary oils, high rearing density and parasitic infections) in the head kidney of gilthead sea bream (Pérez-Sánchez et al., 2011). Additionally, PARK7 is a redox-sensitive chaperone, acting as a sensor of oxidative stress that apparently protects neurons against oxidative stress and cell death, and defects in this gene are the cause of autosomal recessive early-onset Parkinson disease 7 (Bonifati et al., 2003). The presence of this protein in the skin mucus of gilthead sea bream could be viewed, therefore, as part of the antioxidant defense system role of epithelial layers. In this regard, NCSTN might represent another important protein, because in humans it plays a pivotal role in chronic inflammatory skin disease, affecting keratinocyte proliferation, cell-cycle control, and apoptosis (Xiao et al., 2016).

The second node of interconnected skin proteins was composed of 79 proteins involved in protein ubiquitination and antigen presentation pathways with a high representation of major histocompatibility complex, proteasome subunits, ubiquitin enzymes and molecular chaperones, including calnexin, calreticulin and heat shock proteins representative of the six major HSP families based on molecular mass (small HSPs, HSP40, HSP60, HSP70, HSP90 and HSP100) with either cytoplasmic, nuclear plasma membrane or extracellular locations (Table 2). This agrees with the observations made in a previous proteomic gilthead sea bream study, in which more than 1,300 spots were recorded in the skin mucus, but the 100 most abundant were among others ubiquitin/proteasome-related proteins and HSPs (Sanahuja and Ibarz, 2015). Furthermore, in Atlantic cod, changes in proteasome proteins abundance have been reported in response to $V$. anguillarum infection (Rajan et al., 2013) and to challenges with formalin-killed Aeromonas salmonicida (Bricknell et al., 2006). Another protein of interest in this cluster was the beta-2-microglobulin, which is now emerging as a consistent marker of immune system activation ( $\mathrm{Li}$ et al., 
TABLE 3 | Proteins mapped in the overlapping pathways of protein synthesis, cellular assembly and remodeling and non-humoral immune response.

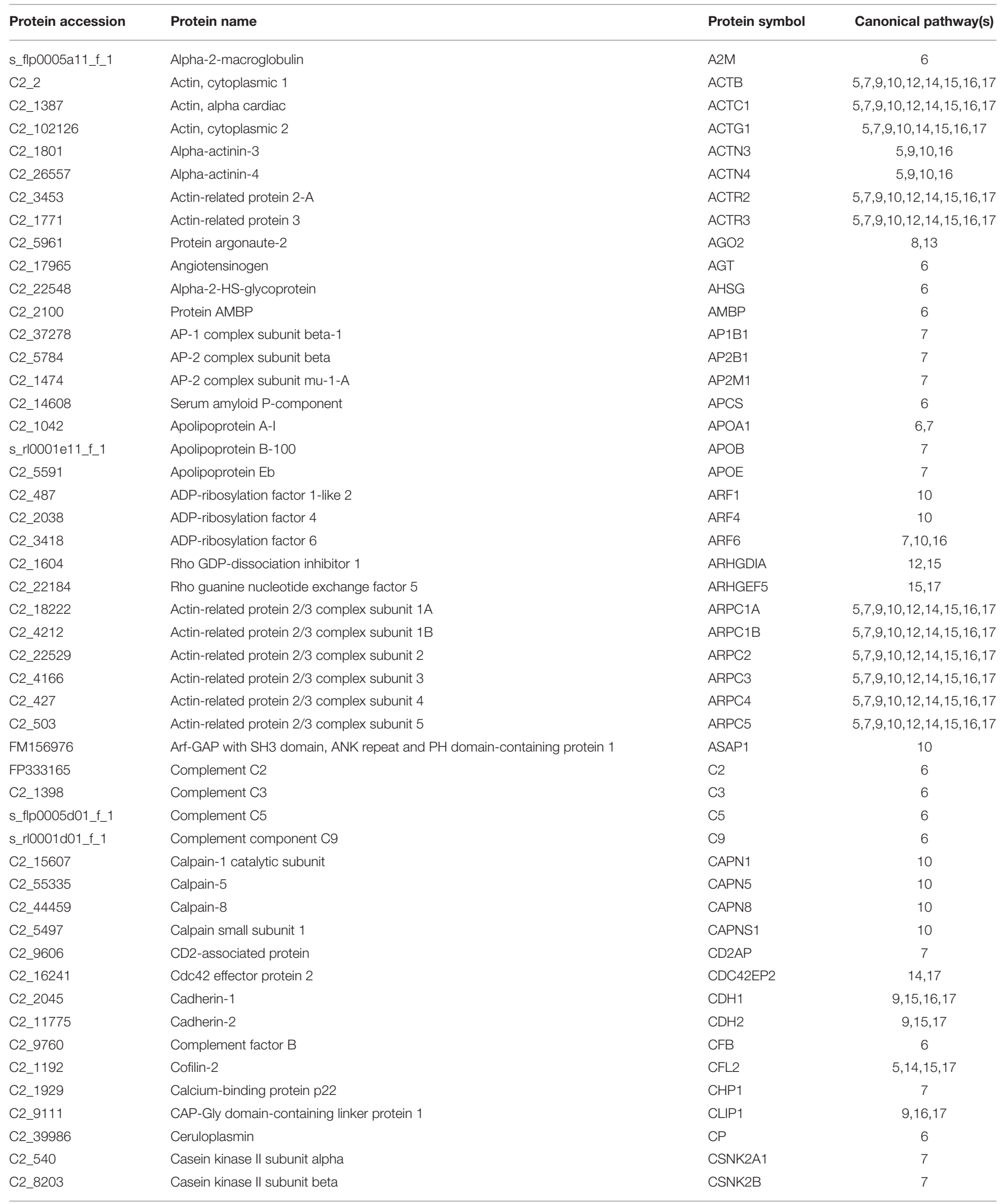


TABLE 3 | Continued

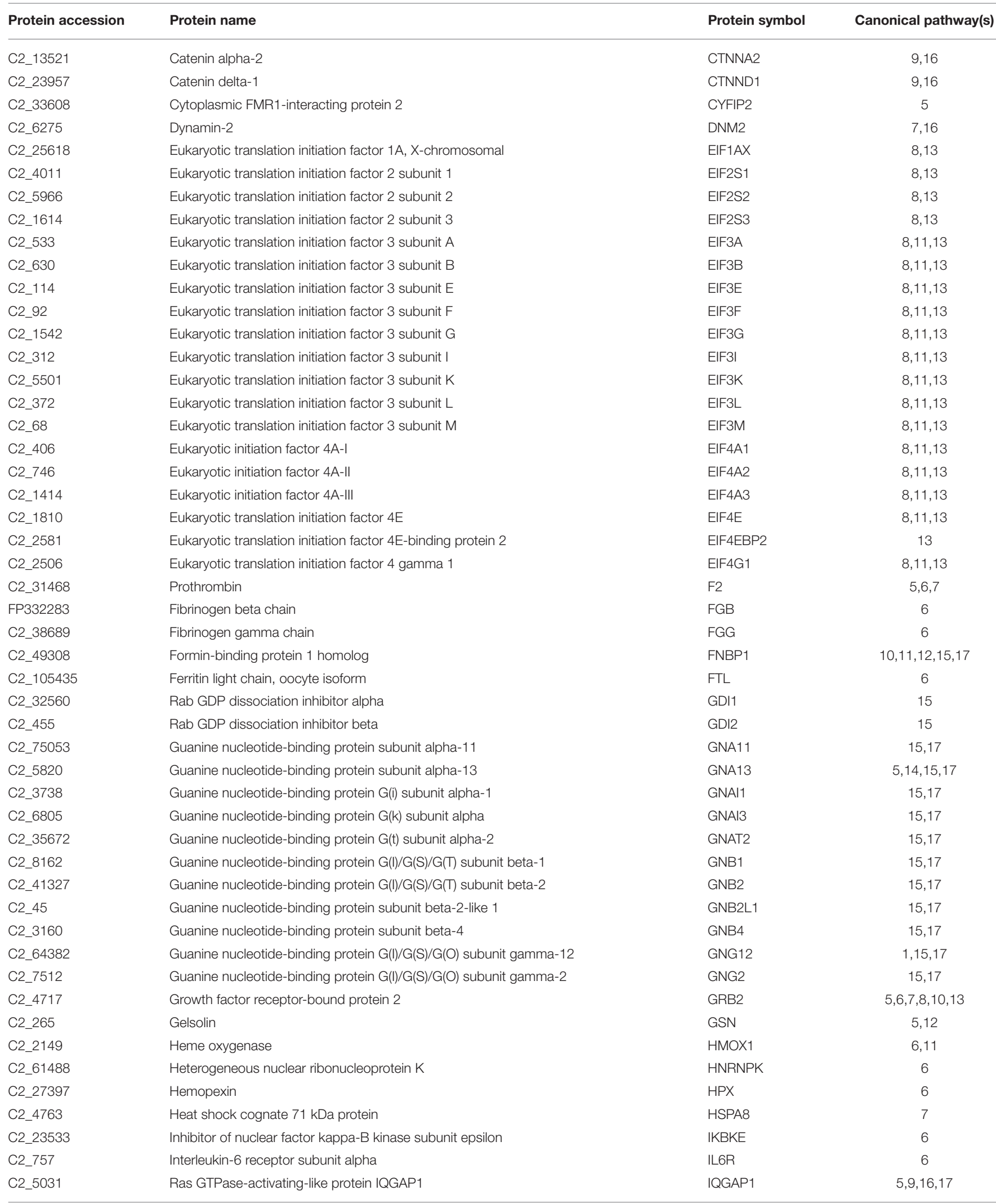


TABLE 3 | Continued

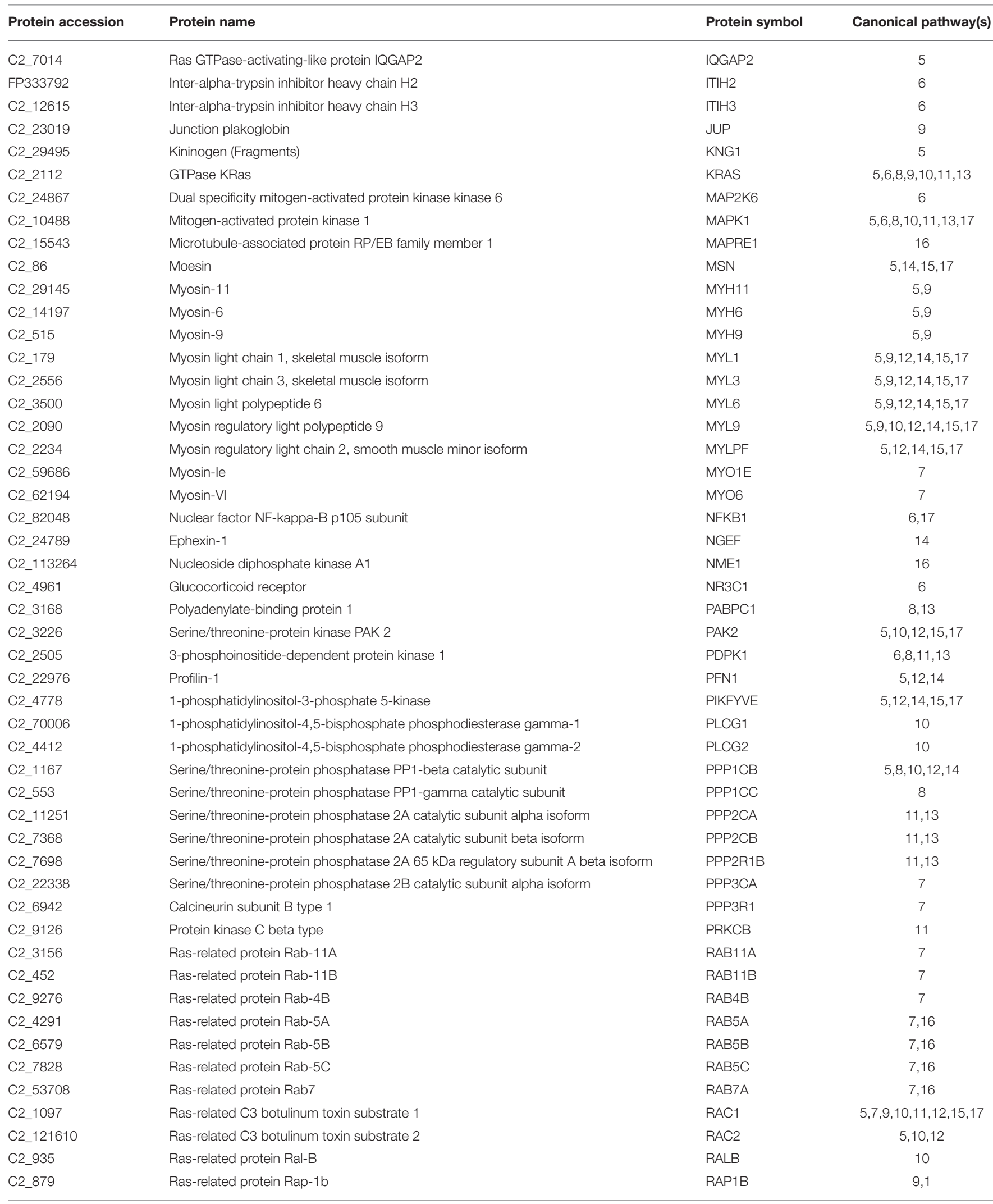


TABLE 3 | Continued

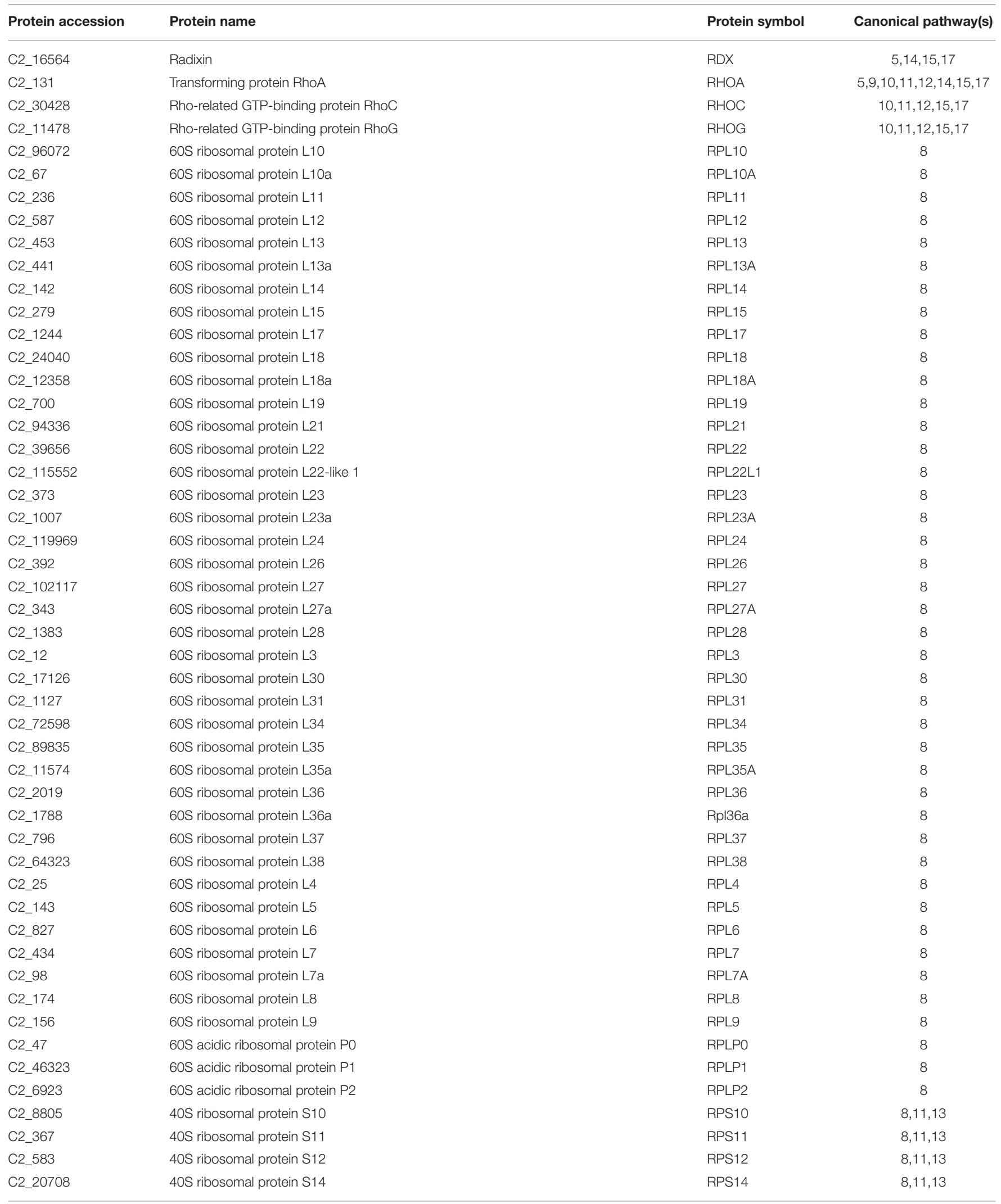


TABLE 3 | Continued

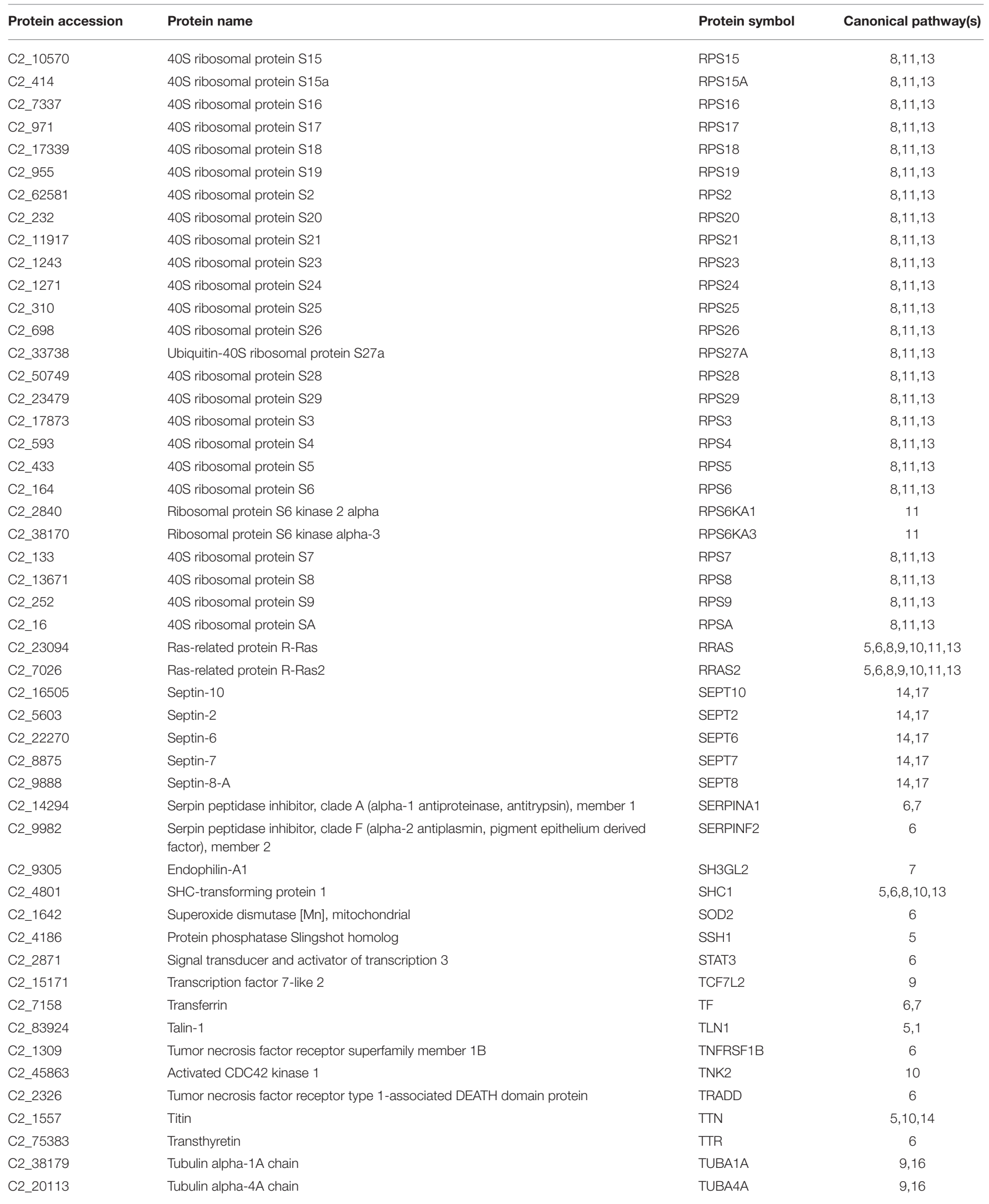


TABLE 3 | Continued

\begin{tabular}{|c|c|c|c|}
\hline Protein accession & Protein name & Protein symbol & Canonical pathway(s) \\
\hline C2_905 & Tubulin beta chain & TUBB & 9,16 \\
\hline C2_90 & Tubulin beta-1 chain & TUBB1 & 9,16 \\
\hline C2_14202 & Tubulin beta-2C chain & TUBB4B & 9,16 \\
\hline C2_6783 & Ubiquitin-60S ribosomal protein L40 & UBA52 & 8 \\
\hline C2_19855 & Probable ubiquitin carboxyl-terminal hydrolase FAF-X & USP9X & 7 \\
\hline C2_9594 & Vinculin & VCL & $5,9,10,16$ \\
\hline C2_3381 & Vimentin & VIM & 17 \\
\hline
\end{tabular}

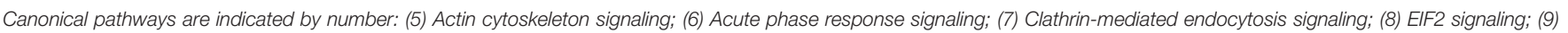

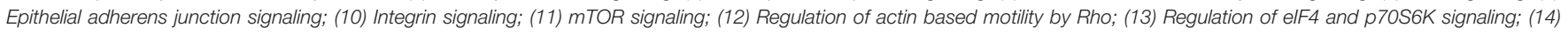
RhoA signaling; (15) RhoGDI signaling; (16) Remodeling of epithelial adherens junctions; (17) Signaling by Rho family GTPase.

TABLE 4 | Protein spots identified as differentially expressed in gilthead sea bream skin mucus after multiple sensorial stress.

\begin{tabular}{|c|c|c|c|c|c|}
\hline $\begin{array}{l}\text { Spot } \\
\text { number }\end{array}$ & $\begin{array}{l}\text { Accession } \\
\text { number }\end{array}$ & Protein name & $p$-value & $\begin{array}{l}\text { Average ratio } \\
\text { (M-ST/CTRL) }\end{array}$ & Identified peptide sequences \\
\hline 743 & C2_534 & Elongation factor 2 & 0.026 & 0.71 & $\begin{array}{l}\text { APLMVYISK/CDLLYEGPPDDEAAMGIK/EGVLCEENMR/FSVSPVVR/GGG } \\
\text { QIIPTAR/GGGQIIPTARR/NCDSKAPLMVYISK/RVLYACELTAEPR/SDPVVS } \\
\text { YR/TILMMGR/VAVEAKNPADLPKNFSGSVSTGLKNFSGSVSTGLKVR/VLYACEL } \\
\text { TAEPR/VMKFSVSPWR }\end{array}$ \\
\hline 815 & C2_1442 & Keratin type II cytoskeletal 8 & 0.014 & 2.71 & ANLEAQIAEAEER/AQYEDIANR/FASFIDKVR/IRDLEDALQR/NLDMDSIVAEVK \\
\hline 1,321 & C2_1442 & Keratin type II cytoskeletal 8 & 0.024 & 1.78 & $\begin{array}{l}\text { DTSVIVEMDNSR/FASFIDKVR/FLEQQNK/IRDLEDALQR/LALDIEIATYRK/NM } \\
\text { QGLVEDFKYYEDEINK/YEDEINKR }\end{array}$ \\
\hline 1,549 & C2_2 & Actin, cytoplasmic 1 & 0.019 & 0.71 & $\begin{array}{l}\text { AGFAGDDAPR/AVFPSIVGRPR/DLTDYLMK/IIAPPERK/LAPSTMKIK/SYELP } \\
\text { DGQVITIGNER }\end{array}$ \\
\hline 1,816 & C2_2 & Actin, cytoplasmic 1 & 0.026 & 0.63 & $\begin{array}{l}\text { DLYANTVLSGGTTMYPGIADR/GYSFTITAER/SYELPDGQVITIGNER/VAPEE } \\
\text { HPVLLTEAPLNPKNAPEEHPVLLTEAPLNPKANR }\end{array}$ \\
\hline 2,181 & C2_785 & $\begin{array}{l}\text { Cytochrome c1, heme } \\
\text { protein mitochondrial }\end{array}$ & 0.018 & 1.64 & LSDYFPKPYPNPESAR/NLVGVSHTEAEVK \\
\hline
\end{tabular}

2016). This small membrane protein is associated with the heavy chains of class I major histocompatibility complex proteins and serum concentrations are elevated in humans during chronic inflammation, liver disease, renal dysfunction, some acute viral infections, and a number of malignancies associated with the B-lymphocyte lineage (Drüeke and Massy, 2009; Shi et al., 2009). However, to our knowledge no previous reports have addressed the presence and regulation of beta-2-microglobulin in the skin mucus of fish.

The third cluster was the most populated one with 257 proteins in 13 interconnected canonical pathways (Table 3). Many of them are involved in protein synthesis (EIF2 signaling, mTOR signaling) and the maintenance of epithelial integrity (remodeling of epithelial adherens junctions, regulation of actin-based motility by Rho, epithelial adherens junction signaling, etc.) with also an important representation of proteins of acute phase response signaling. This set of proteins included among others, alpha-2-HS-glycoprotein, alpha-2macroglobulin, amyloid P component, apolipoprotein A-I, angiotensinogen, ceruloplasmin, complement component 2, 3, 5 , and 9 , complement factor $\mathrm{B}$, ferritin, fibrinogen, hemopexin, inter-alpha-trypsin inhibitor heavy chain $\mathrm{H} 2$ and $\mathrm{H} 3$, serpin peptidase inhibitor, transthyretin and transferrin. Most of them have been reported in other proteomic studies of mucosal surfaces, being this finding consistent with a key role of mucosal immunity during the course of most fish infections, probably due to the fact that aquatic environment favors a more intimate contact with pathogens (Salinas et al., 2011; Esteban, 2012). We are still far from fully exploiting this information on a routine basis, but our study will contribute to enlarge the list of immunerelevant proteins that are susceptible to be included in protein arrays or more targeted immune kits.

\section{Stress-Regulated Proteins}

Principal components analysis from image processing of 2-DE of the mucus proteins from control CTRL vs. M-ST did not clearly separate individuals from both groups (Figure S1). Thus, only six spots were found to show a different significant ( $p$-value $<0.03$ ) abundance in stressed fish, with three upregulated (fold-change $1.6-2.7)$ and three down-regulated $(0.6-0.7)$ proteins. The six protein spots were unequivocally identified by comparing the LCMS/MS data with the gilthead sea bream transcriptome database, with a $100 \%$ of identity for all peptide sequences with the corresponding accession (Table 4). Down-regulated spots were elongation factor 2 (spot 743; GenBank accession KY388506) and cytoplasmic actin (spots 1,549 and 1,816; GenBank accession KY388507). Spot 2,181 (fold-change 1.64) was identified as the mitochondrial protein cytochrome $\mathrm{cl}$ heme (GenBank accession 


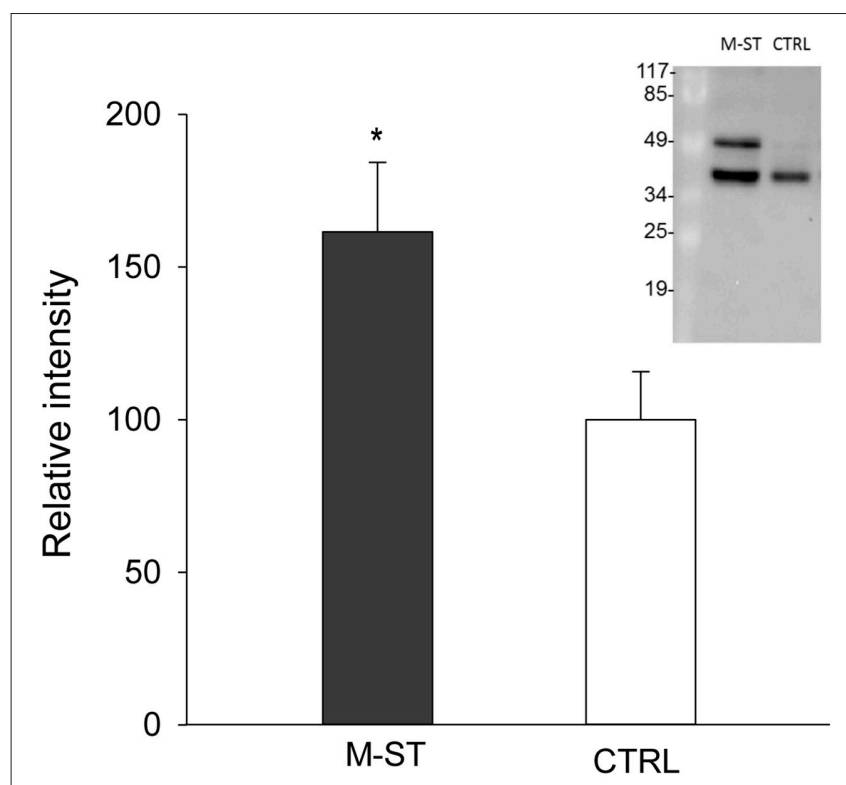

FIGURE 2 | Relative keratin type II cytoskeletal 8 protein levels in skin mucus of multiple sensorial stressed fish (M-ST) and control unstressed fish (CTRL). Values of expression relative to control are the mean \pm SEM of eight individuals. Asterisk indicated significant differences $(p<0.05$, Student's $t$-test) between groups. Insert shows a representative western blot using the rabbit anti-human cytokeratin 8 antibody.

KC217621), whereas the two most upregulated spots (spots $815,1,321)$ were both recognized as keratin type II cytoskeletal 8 (GenBank accession KY388508). The higher abundance of immunoreactive cytokeratin 8 proteins in the mucus of M-ST fish was confirmed by Western blot (Figure 2), where the most abundant band was that of lower molecular weight $(38-40 \mathrm{kDa})$. Cytokeratin 8 is a highly modified protein, but our working hypothesis is that this band was a proteolytically cleaved form. Protein spots, representing type I or type II keratin fragments, have also been reported at different stages of development in amphibians (Domanski and Helbing, 2007) and Atlantic cod larvae (Sveinsdóttir et al., 2008). Likewise, different fragments of cytokeratin 8 were detected by immunoblotting in colorectal biopsies of human cancer patients (Khan et al., 2011). Of note, gilthead sea bream cytokeratine 8 has a high identity (61\%) and homology (69\%) with the same protein of human origin, but the identified peptide sequences matched exactly with the gilthead sea bream protein sequence and not with that of human, so the risk of potential handling contamination was discarded.

Clear evidence for the prominent mechanical function of keratins comes from multiple human diseases and murine knockouts. However, distinct keratins emerge as highly dynamic scaffolds contributing to cell size determination, translation control, proliferation, malignant transformation and various stress responses (Magin et al., 2007; Loschke et al., 2015). Importantly, this also applies to fish and different reports show that keratins from skin mucus possess anti-bacterial activity owing to their pore-forming properties (Molle et al.,
2008; Rajan et al., 2011). Relatively little is known about the precise mechanisms responsible for assembly and pathology, although it has been suggested that keratins can act as a "phosphate sponge" absorbing the stress-activated phosphate kinases, thereby, reducing their adverse effect and protecting cells from injury (Ku and Omary, 2006). Indeed, differential regulation of keratin phosphorylation is related to intricate functional properties of specific epithelial cell types (Tao et al., 2006; Busch et al., 2012; Majumdar et al., 2012). In our case, changes in the abundance of cytokeratin 8 in the skin mucus of gilthead sea bream would support some type of epithelia damage in fish diagnosed as chronically stressed, showing reduced growth and feed conversion efficiency, strong-down regulation of markers of mitochondrial activity and biogenesis in combination with a high variable and non-significant increase of plasma cortisol levels (Bermejo-Nogales et al., 2014). Since aerobic metabolism is the most important source of reactive oxygen species (ROS), this mitochondrial metabolic feature was considered as part of the adaptive stress response that reduced ROS production when fish face an increased risk of oxidative stress in our stress model that mimicked daily farming activities. The magnitude of the changes observed in the skin mucus proteome was, however, lower than expected. It can be argued that this fact might reflect the high allostatic capacity of our fish strain to cope with chronic stress. Indeed, in other less intrusive models of chronic stress, fish were intensively chased for 5 min 2 times per day after lowering water level and data on growth parameters evidenced a real stress adaptation with a switch from aerobic to more anaerobic metabolism without changes in plasma cortisol levels (Bermejo-Nogales et al., 2014). Additionally, other factors including season, age and nutritional background should be considered in an holistic manner to ultimately understand the extent to which the skin mucus proteome of gilthead sea bream is regulated by environmental and nutritional stressors, helping to understand how stress condition can be fine evaluated at the farm scale level without evoking further stress.

\section{CONCLUSIONS}

A high resolution mass spectrometry-based proteomic approach was able to identify 2,062 proteins in the skin mucus of gilthead bream after matching in a homologous protein database. Three major clusters with more than 350 proteins were retained after filtering by canonical pathway overlapping. Among them, proteins of oxidative phosphorylation, mitochondrial dysfunction, protein ubiquitination, immune response, epithelial remodeling, and cellular assembly were highly represented. This was reinforced by the observation that major changes related to the abundance of cytokeratin 8 in the skin mucus of stressed fish under our experimental model of chronic stress were found by means of 2-DE methodology and confirmed by immunoblotting. All this information will be useful in developing more targeted approaches that address specific changes in the skin mucus proteome of farmed fish, with special emphasis on markers of skin epithelial cell turnover. 


\section{AUTHOR CONTRIBUTIONS}

JP, RO, and AS conceived and designed the study. OF supervised animal handling and sampling. JP, GT, PS, SR, and JC performed protein identification and functional characterization of mucus proteome and stress-regulated proteins. JP and PS conducted Western blot analysis. JP, GT, AS, and JC wrote the manuscript. All authors read and approved the final manuscript.

\section{FUNDING}

This study was funded by the European Union (AQUAEXCEL, FP7/2007/2013; grant agreement No. 262336, Aquaculture infrastructures for excellence in European fish research) project. The views expressed in this work are the sole responsibility of the authors and do not necessarily reflect

\section{REFERENCES}

Agosto, M., Azrin, M., Singh, K., Jaffe, A. S., and Liang, B. T. (2011). Serum caspase-3 p17 fragment is elevated in patients with ST-segment elevation myocardial infarction: a novel observation. J. Am. Coll. Cardiol. 57, 220-221. doi: 10.1016/j.jacc.2010.08.628

Ai-Jun, M., Zhi-Hui, H., and Xin-An, W. (2013). Changes in protein composition of epidermal mucus in turbot Scophthalmus maximus (L.) under high water temperature. Fish Physiol. Biochem. 39, 1411-1418. doi: 10.1007/s10695-013-9795-5

Alban, A., David, S. O., Bjorkesten, L., Andersson, C., Sloge, E., Lewis, S., et al. (2003). A novel experimental design for comparative two-dimensional gel analysis: Two-dimensional difference gel electrophoresis incorporating a pooled internal standard. Proteomics 3, 36-44. doi: 10.1002/pmic.200390006

Arends, R. J., Mancera, J. M., Muñoz, J. L., Wendelaar Bonga, E. S., and Flik, G. (1999). The stress response of the gilthead sea bream (Sparus aurata L.) to air exposure and confinement. J. Endocrinol. 163, 149-157. doi: $10.1677 /$ joe. 0.1630149

Benedito-Palos, L., Ballester-Lozano, G., and Pérez-Sánchez, J. (2014). Wide-gene expression analysis of lipid-relevant genes in nutritionally challenged gilthead sea bream (Sparus aurata). Gene 547, 34-42. doi: 10.1016/j.gene.2014.05.073

Bennike, T., Ayturk, U., Haslauer, C. M., Froehlich, J. W., Proffen, B. L., Barnaby, O., et al. (2014). A normative study of the synovial fluid proteome from healthy porcine knee joints. J. Proteome Res. 13, 4377-4387. doi: 10.1021/pr500587x

Bermejo-Nogales, A., Nederlof, M., Benedito-Palos, L., Ballester-Lozano, G. F., Folkedal, O., Olsen, R. E., et al. (2014). Metabolic and transcriptional responses of gilthead sea bream (Sparus aurata L.) to environmental stress: new insights in fish mitochondrial phenotyping. Gen. Comp. Endocrinol. 205, 305-315. doi: 10.1016/j.ygcen.2014.04.016

Bonifati, V., Rizzu, P., van Baren, M. J., Schaap, O., Breedveld, G. J., Krieger, E., et al. (2003). Mutations in the DJ-1 gene associated with autosomal recessive early-onset parkinsonism. Science 299, 256-259. doi: 10.1126/science.1077209

Bratland, S., Stien, L. H., Braithwaite, V., Juell, J.-E., Folkedal, O., Nilsson, J., et al. (2010). From fear to anticipation. Using aversive light stimuli to train reward conditioning in Atlantic salmon (Salmo salar L.). Aquacult. Int. 18, 991-1001. doi: 10.1007/s10499-009-9317-8

Bricknell, I. R., Bron, J. E., and Bowden, T. J. (2006). Diseases of gadoid fish in cultivation: a review. ICES J. Mar. Sci. 63, 253-266. doi: 10.1016/j.icesjms.2005.10.009

Busch, T., Armacki, M., Eiseler, T., Joodi, G., Temme, C., Jansen, J., et al. (2012). Keratin 8 phosphorylation regulates keratin reorganization and migration of epithelial tumor cells. J. Cell Sci. 125, 2148-2159. doi: 10.1242/jcs.080127

Calduch-Giner, J. A., Bermejo-Nogales, A., Benedito-Palos, L., Estensoro, I., Ballester-Lozano, G., Sitjà-Bobadilla, A., et al. (2013). Deep sequencing for de novo construction of a marine fish (Sparus aurata) transcriptome database the views of the European Commission. Additional funding was obtained from the Spanish Ministerio de Economía y Competitividad (MI2-Fish, AGL2013-48560) and from Generalitat Valenciana (PROMETEO FASE II-2014/085). Proteomics study was done at Proteomics laboratory of University of Valencia, Spain (SCSIE). This laboratory is a member of Proteored, PRB2-ISCIII and is supported by grant PT13/0001, of the PE I+D+i 2013-2016, funded by Instituto de Salud Carlos III and Fondo Europeo de Desarrollo Regional (FEDER).

\section{SUPPLEMENTARY MATERIAL}

The Supplementary Material for this article can be found online at: http://journal.frontiersin.org/article/10.3389/fphys. 2017.00034/full\#supplementary-material

with a large coverage of protein-coding transcripts. BMC Genomics 14:178. doi: 10.1186/1471-2164-14-178

Calduch-Giner, J. A., Davey, G., Saera-Vila, A., Houeix, B., Talbot, A., Prunet, P., et al. (2010). Use of microarray technology to assess the time course of liver stress response after confinement exposure in gilthead sea bream (Sparus aurata L.). BMC Genomics 11:193. doi: 10.1186/1471-2164-11-193

Chong, K., Joshi, S., Jin, L. T., and Shu-Chien, A. C. (2006). Proteomics profiling of epidermal mucus secretion of a cichlid (Symphysodon aequifasciata) demonstrating parental care behavior. Proteomics 6, 2251-2258. doi: 10.1002/pmic.200500591

Cone, R. A. (2009). Barrier properties of mucus. Adv. Drug Del. Rev. 61, 75-85. doi: 10.1016/j.addr.2008.09.008

Cordero, H., Brinchmann, M. F., Cuesta, A., Meseguer, J., and Esteban, M. A. (2015). Skin mucus proteome map of European sea bass (Dicentrarchus labrax). Proteomics 15, 4007-4020. doi: 10.1002/pmic.201500120

Cordero, H., Morcillo, P., Cuesta, A., Brinchmann, M. F., and Esteban, M. A. (2016). Differential proteome profile of skin mucus of gilthead seabream (Sparus aurata) after probiotic intake and/or overcrowding stress. J. Proteomics 132, 41-50. doi: 10.1016/j.jprot.2015.11.017

de Souza, G. A., Godoy, L. M., and Mann, M. (2006). Identification of 491 proteins in the tear fluid proteome reveals a large number of proteases and protease inhibitors. Genome Biol. 7:R72. doi: 10.1186/gb-2006-7-8-R72

Dharmani, P., Srivastava, V., Kissoon-Singh, V., and Chadee, K. (2009). Role of intestinal mucins in innate host defense mechanisms against pathogens. J. Innate Immun. 1, 123-135. doi: 10.1159/000163037

Dickens, M. J., and Romero, L. M. (2013). A consensus endocrine profile for a chronically stressed wild animal does not exist. Gen. Comp. Endocrinol. 191, 177-189. doi: 10.1016/j.ygcen.2013.06.014

Domanski, D., and Helbing, C. C. (2007). Analysis of the Rana catesbeiana tadpole tail fin proteome and phosphoproteome during T3-induced apoptosis: identification of a novel type I keratin. BMC Dev. Biol. 7:94. doi: 10.1186/1471-213X-7-94

Drüeke, T. B., and Massy, Z. A. (2009). Beta2-microglobulin. Semin. Dial. 22, 378-380. doi: 10.1111/j.1525-139X.2009.00584.x

Dzul-Caamal, R., Olivares-Rubio, H. F., Salazar-Coria, L., Rocha-Gómez, M. A., and Vega-López, A. (2016). Multivariate analysis of biochemical responses using non-invasive methods to evaluate the health status of the endangered blackfin goodeid (Girardinichthys viviparus). Ecol. Indicat. 60, 1118-1129. doi: 10.1016/j.ecolind.2015.09.017

Easy, R. H., and Ross, N. W. (2009). Changes in Atlantic salmon (Salmo salar) epidermal mucus protein composition profiles following infection with sea lice (Lepeophtheirus salmonis). Comp. Biochem. Physiol. D 4, 159-167. doi: 10.1016/j.cbd.2009.02.001

Ekman, D. R., Skelton, D. M., Davis, J. M., Villeneuve, D. L., Cavallin, J. E., Schroeder, A., et al. (2015). Metabolite profiling of fish skin mucus: a novel 
approach for minimally-invasive environmental exposure monitoring and surveillance. Environ. Sci. Technol. 49, 3091-3100. doi: 10.1021/es505054f

Ellis, A. E. (2001). Innate host defense mechanisms of fish against viruses and bacteria. Dev. Comp. Immunol. 25, 827-839. doi: 10.1016/S0145-305X(01)00038-6

Esteban, M. A. (2012). An overview of the immunological defenses in fish skin. ISRN Immunol. 29:853470. doi: 10.5402/2012/853470

Fanouraki, E., Mylonas, C. C., Papandroulakis, N., and Pavlidis, M. (2011). Species specificity in the magnitude and duration of the acute stress response in Mediterranean marine fish in culture. Gen. Comp. Endocrinol. 173, 313-322. doi: 10.1016/j.ygcen.2011.06.004

Fletcher, T. C., and Grant, P. T. (1969). Immunoglobulins in the serum and mucus of the plaice (Pleuronectes platessa). Biochem. J. 115:65. doi: $10.1042 /$ bj1150065P

Guardiola, F. A., Cuesta, A., Arizcun, M., Meseguer, J., and Esteban, M. A. (2014). Comparative skin mucus and serum humoral defense mechanisms in the teleost gilthead seabream (Sparus aurata). Fish. Shellfish. Immunol. 36, 545-551. doi: 10.1016/j.fsi.2014.01.001

Hjelmeland, K., Christie, M., and Raa, J. (1983). Skin mucus protease from rainbow trout Salmo gairdneri Richardson and its biological significance. J. Fish. Biol. 23, 13-22. doi: 10.1111/j.1095-8649.1983.tb02878.x

Ibarz, A., Blasco, J., Sala-Rabanal, M., Gallardo, M. A., Redondo, A., and Fernández-Borràs, J. (2007). Metabolic rate and tissue reserves in gilthead sea bream (Sparus aurata) under thermal fluctuations and fasting, and their capacity for recovery. Can. J. Fish Aquat. Sci. 64, 1034-1042. doi: 10.1139/f07-079

Iq, K. C., and Shu-Chien, A. C. (2011). Proteomics of buccal cavity mucus in female tilapia fish (Oreochromis spp.): a comparison between parental and non-parental fish. PLOS ONE 6:e18555. doi: 10.1371/journal.pone.00 18555

Jurado, J., Fuentes-Almagro, C. A., Guardiola, F. A., Cuesta, A., Esteban, M. Á., and Prieto-Álamo, M. J. (2015). Proteomic profile of the skin mucus of farmed gilthead seabream (Sparus aurata). J. Proteomics 120, 21-34. doi: 10.1016/j.jprot.2015.02.019

Khan, A. Q., Bury, J. P., Brown, S. R., Riley, S. A., and Corfe, B. M. (2011). Keratin 8 expression in colon cancer associates with low faecal butyrate levels. BMC Gastroenterology 11:2. doi: 10.1186/1471-230X-11-2

$\mathrm{Ku}$, N. O., and Omary, M. B. (2006). A disease and phosphorylation related non-mechanical function for keratin 8. J. Cell. Biol. 174, 115-125. doi: $10.1083 /$ jcb. 200602146

Lee, J. M., Garon, E., and Wong, D. T. (2009). Salivary diagnostics. Orthod. Craniofac. Res. 12, 206-211. doi: 10.1111/j.1601-6343.2009.01454.x

Leyens, G., Donnay, I., and Knoops, B. (2003). Cloning of bovine peroxiredoxinsgene expression in bovine tissues and amino acid sequence comparison with rat, mouse and primate peroxiredoxins. Comp. Biochem. Physiol. B 136, 943-955. doi: 10.1016/S1096-4959(03)00290-2

Li, L., Dong, M., and Wang, X. G. (2016). The implication and significance of beta 2 microglobulin: A conservative multifunctional regulator. Chin. Med. J. 129, 448-455. doi: 10.4103/0366-6999.176084

Loschke, F., Seltmann, K., Bouameur, J. E., and Magin, T. M. (2015). Regulation of keratin network organization. Curr. Opin. Cell Biol. 32, 56-64. doi: 10.1016/j.ceb.2014.12.006

Magin, T. M., Vijayaraj, P., and Leube, R. E. (2007). Structural and regulatory functions of keratins. Exp. Cell Res. 313, 2021-2032. doi: 10.1016/j.yexcr.2007.03.005

Majumdar, D., Tiernan, J. P., Lobo, A. J., Evans, C. A., and Corfe, B. M. (2012). Keratins in colorectal epithelial function and disease. Int. J. Exp. Pathol. 93, 305-318. doi: 10.1111/j.1365-2613.2012.00830.x

Mancuso, M. (2012). Photobacteriosis exchange between wild and farmed fish in the Mediterranean area. J. Aquacult. Res. Dev. 3, 3-6. doi: 10.4172/2155-9546.1000e102

Marimuthu, A., O’Meally, R. N., Chaerkady, R., Subbannayya, Y., Nanjappa, V., Kumar, P., et al. (2011). A comprehensive map of the human urinary proteome. J. Proteome Res. 10, 2734-2743. doi: 10.1021/pr2003038

Molle, V., Campagna, S., Bessin, Y., Ebran, N., Saint, N., and Molle, G. (2008). First evidence of the pore-forming properties of a keratin from skin mucus of rainbow trout (Oncorhynchus mykiss, formerly Salmo gairdneri). Biochem. J. 411, 33-40. doi: 10.1042/BJ20070801
Montero, D., Terova, G., Rimoldi, S., Betancor, M. B., Atalah, E., Torrecillas, S., et al. (2015a). Modulation of the expression of components of the stress response by dietary arachidonic acid in European sea bass (Dicentrarchus labrax) larvae. Lipids 50, 1029-1041. doi: 10.1007/s11745-015-4057-1

Montero, D., Terova, G., Rimoldi, S., Tort, L., Negrin, D., Zamorano, M. J., et al. (2015b). Modulation of adrenocorticotrophin hormone (ACTH)-induced expression of stress-related genes by PUFA in inter-renal cells from European sea bass (Dicentrarchus labrax). J. Nutr. Sci. 4:e16. doi: 10.1017/jns.2015.6

Negus, V. E. (1963). The functions of mucus. Acta Oto-laryngologica 56, 204-214. doi: 10.3109/00016486309127406

Nilsson, J., Stien, L. H., Fosseidengen, J. E., Olsen, R. E., and Kristiansen, T. S. (2012). From fright to anticipation: reward conditioning versus habituation to a moving dip net in farmed Atlantic cod (Gadus morhua). Appl. Anim. Behav. Sci. 138, 118-124. doi: 10.1016/j.applanim.2012.02.014

Pankhurst, N. W. (2011). The endocrinology of stress in fish: an environmental perspective. Gen. Comp. Endocrinol. 170, 265-275. doi: 10.1016/j.ygcen.2010.07.017

Pérez-Sánchez, J., Bermejo-Nogales, A., Calduch-Giner, J. A., Kaushik, S., and Sitjà-Bobadilla, A. (2011). Molecular characterization and expression analysis of six peroxiredoxin paralogous genes in gilthead sea bream (Sparus aurata): Insights from fish exposed to dietary, pathogen and confinement stressors. Fish Shellfish Immunol. 31, 294-302. doi: 10.1016/j.fsi.2011.05.015

Pérez-Sánchez, J., Borrel, M., Bermejo-Nogales, A., Benedito-Palos, L., Saera-Vila, A., Calduch-Giner, J. A., et al. (2013a). Dietary oils mediate cortisol kinetics and the hepatic mRNA expression profile of stress-responsive genes in gilthead sea bream (Sparus aurata) exposed to crowding stress. Implications on energy homeostasis and stress susceptibility. Comp. Biochem. Physiol. D 8, 123-130. doi: 10.1016/j.cbd.2013.02.001

Pérez-Sánchez, J., Estensoro, I., Redondo, M. J., Calduch-Giner, J. A., Kaushik, S., and Sitjà-Bobadilla, A. (2013b). Mucins as diagnostic and prognostic biomarkers in a fish-parasite model: transcriptional and functional analysis. PLoS ONE 8:e65457. doi: 10.1371/journal.pone.0065457

Perkins, A., Nelson, K. J., Parsonage, D., Poole, L. B., and Karplus, P. A. (2015). Peroxiredoxins: guardians against oxidative stress and modulators of peroxide signaling. Trends Biochem. Sci. 40, 435-445. doi: 10.1016/j.tibs.2015.05.001

Pottinger, T. G. (2008). "The stress response in fish-mechanisms, effects and measurement, in fish welfare," in Fish Welfare, ed. E. J. Branson (Oxford: Blackwell Publishing Ltd.), 32-48. doi: 10.1002/9780470697610.ch3

Provan, F., Jensen, L. B., Uleberg, K. E., Larssen, E., Rajalahti, T., Mullins, J., et al. (2013). Proteomic analysis of epidermal mucus from sea lice-infected Atlantic salmon, Salmo salar L. J. Fish. Dis. 36, 311-321. doi: 10.1111/jfd.12064

Rajan, B., Fernandes, J. M., Caipang, C. M., Kiron, V., Rombout, J. H., and Brinchmann, M. F. (2011). Proteome reference map of the skin mucus of Atlantic cod (Gadus morhua) revealing immune competent molecules. Fish Shellfish Immunol. 31, 224-231. doi: 10.1016/j.fsi.2011.05.006

Rajan, B., Lokesh, J., Kiron, V., and Brinchmann, M. F. (2013). Differentially expressed proteins in the skin mucus of Atlantic cod (Gadus morhua) upon natural infection with Vibrio anguillarum. BMC Vet. Res. 9:103. doi: $10.1186 / 1746-6148-9-103$

Ren, Y., Zhao, H., Su, B., Peatman, E., and Li, C. (2015). Expression profiling analysis of immune-related genes in channel catfish (Ictalurus punctatus) skin mucus following Flavobacterium columnare challenge. Fish Shellfish Immunol. 46, 537-542. doi: 10.1016/j.fsi.2015.07.021

Rimoldi, S., Benedito-Palos, L., Terova, G., and Pérez-Sánchez, J. (2016). Wide-targeted gene expression infers tissue-specific molecular signatures of lipid metabolism in fed and fasted fish. Rev. Fish Biol. Fish. 26, 93-108. doi: 10.1007/s11160-015-9408-8

Rimoldi, S., Terova, G., Ceccuzzi, P., Marelli, S., Antonini, M., and Saroglia, M. (2012). HIF-1a mRNA levels in Eurasian perch (Perca fluviatilis) exposed to acute and chronic hypoxia. Mol. Biol. Rep. 39, 4009-4015. doi: 10.1007/s11033-011-1181-8

Rotllant, J., Balm, P. H., Ruane, N. M., Pérez-Sánchez, J., Wendelaar-Bonga, S. E., and Tort, L. (2000). Pituitary proopiomelanocortin-derived peptides and hypothalamus-pituitary-interrenal axis activity in gilthead sea bream during crowding stress: differential regulation of adrenocorticotropin hormone and melanocyte-stimulating hormone release by corticotropin-releasing hormone and thyrotropin-releasing hormone. Gen. Comp. Endocrinol. 119, 152-163. doi: 10.1006/gcen.2000.7508 
Salinas, I., Zhang, Y. A., and Sunyer, J. O. (2011). Mucosal immunoglobulins and B cells of Teleost fish. Dev. Comp. Immunol. 35, 1346-1365. doi: $10.1016 /$ j.dci.2011.11.009

Sanahuja, I., and Ibarz, A. (2015). Skin mucus proteome of gilthead sea bream: a non-invasive method to screen for welfare indicators. Fish Shellfish Immunol. 46, 426-435. doi: 10.1016/j.fsi.2015.05.056

Sánchez-Juanes, F., Muñiz, M. C., Raposo, C., Rodríguez-Prieto, S., Paradela, A., Quiros, Y., et al. (2013). Unveiling the rat urinary proteome with three complementary proteomics approaches. Electrophoresis 34, 2473-2483. doi: 10.1002/elps.201200689

Schempp, C., Emde, M., and Wölfle, U. (2009). Dermatology in the Darwin anniversary. Part 1: Evolution of the integument. J. German Soc. Dermatol. 7, 750-757. doi: 10.1111/j.1610-0387.2009.07193.x

Shephard, K. L. (1994). Functions for fish mucus. Rev. Fish. Biol. Fish 4, 401-429. doi: 10.1007/BF00042888

Shi, C., Zhu, Y., Su, Y., Chung, L. W., and Cheng, T. (2009). Beta2-microglobulin: Emerging as a promising cancer therapeutic target. Drug Discov. Today 14, 25-30. doi: 10.1016/j.drudis.2008.11.001

Shiomi, K., Uematsu, H., Yamanaka, H., and Kikuchi, T. (1988). Screening of lectins in fish skin mucus. J. Tokyo Univ. Fish. 75, 145-152. doi: $10.1074 /$ jbc.M109.002873

Srinivasula, S. M., and Ashwell, J. D. (2008). IAPs: What's in a name? Mol. Cell. 30, 123-135. doi: 10.1016/j.molcel.2008.03.008

Subramanian, S., Ross, N. W., and Mackinnon, S. L. (2008). Comparison of the biochemical composition of normal epidermal mucus and extruded slime of hagfish (Myxine glutinosa L.). Fish Shellfish Immunol. 25, 625-632. doi: 10.1016/j.fsi.2008.08.012

Sveinsdóttir, H., Vilhelmsson, O., and Gudmundsdótti, A. (2008). Proteome analysis of abundant proteins in two age groups of early Atlantic cod (Gadus morhua) larvae. Comp. Biochem. Physiol. D 3, 243-250. doi: 10.1016/j.cbd.2008.06.001

Tacchi, L., Lowrey, L., Musharrafieh, R., Crossey, K., Larragoite, E. T., and Salinas, I. (2015). Effects of transportation stress and addition of salt to transport water on the skin mucosal homeostasis of rainbow trout (Oncorhynchus mykiss). Aquaculture 435, 120-127. doi: 10.1016/j.aquaculture.2014.09.027

Tao, G. Z., Toivola, D. M., Zhou, Q., Strnad, P., Xu, B., Michie, S. A., et al. (2006). Protein phosphatase-2A associates with and dephosphorylates keratin 8 after hyposmotic stress in a site- and cell-specific manner. J. Cell. Sci. 119, 1425-1432. doi: $10.1242 /$ jcs.02861
Terova, G., Gornati, R., Rimoldi, S., Bernardini, G., and Saroglia, M. (2005). Quantification of a glucocorticoid receptor in sea bass (Dicentrarchus labrax, L.) reared at high stocking density. Gene 357, 144-151. doi: 10.1016/j.gene.2005.06.016

Terova, G., Rimoldi, S., Brambilla, F., Gornati, R., Bernardini, G., and Saroglia, M. (2009). In vivo regulation of GLUT2 mRNA in sea bass (Dicentrarchus labrax) in response to acute and chronic hypoxia. Comp. Biochem. Physiol. B 152, 306-316. doi: 10.1016/j.cbpb.2008.12.011

Tort, L., Montero, D., Robaina, L., Fernández-Palacios, H., and Izquierdo, M. S. (2001). Consistency of stress response to repeated handling in the gilthead sea bream Sparus aurata Linnaeus, 1758. Aquaculture Res. 32, 593-598. doi: 10.1046/j.1365-2109.2001.00607.x

van de Winkel, J. G. J., van Kuppevelt, T. H. M. S. M., Janssen, H. M. J., and Lock, R. A. C. (1986). Glycosaminoglycans in the skin mucus of rainbow trout (Salmo gairdneri). Comp. Biochem. Physiol. C 68, 234-237. doi: 10.1016/0305-0491(86)90030-1

Vatsos, I., Kotzamanis, Y., Henry, M., Angelidis, P., and Alexis, M. (2010). Monitoring stress in fish by applying image analysis to their skin mucous cells. Eur. J. Histochem. 54:e22. doi: 10.4081/ejh.2010.e22

Winiarczyk, M., Winiarczyk, D., Banach, T., Adaszek, L., Madany, J., Mackiewicz, J., et al. (2015). Dog tear film proteome indepth analysis. PLoS ONE 10:e0144242. doi: 10.1371/journal.pone. 0144242

Xiao, X., He, Y., Li, C., Zhang, X., Xu, H., and Wang, B. (2016). Nicastrin mutations in familial acne inversa impact keratinocyte proliferation and differentiation through Notch and PI3K-AKT signaling pathways. Br. J. Dermatol. 174, 522-532. doi: 10.1111/bjd.14223

Conflict of Interest Statement: The authors declare that the research was conducted in the absence of any commercial or financial relationships that could be construed as a potential conflict of interest.

Copyright (C) 2017 Pérez-Sánchez, Terova, Simó-Mirabet, Rimoldi, Folkedal, Calduch-Giner, Olsen and Sitjà-Bobadilla. This is an open-access article distributed under the terms of the Creative Commons Attribution License (CC BY). The use, distribution or reproduction in other forums is permitted, provided the original author(s) or licensor are credited and that the original publication in this journal is cited, in accordance with accepted academic practice. No use, distribution or reproduction is permitted which does not comply with these terms. 